\title{
Communicating uncertainty in the IPCC's greenhouse gas emissions scenarios
}

\author{
Niels J. Schenk • Sander M. Lensink
}

Received: 7 March 2005 / Accepted: 9 October 2006 / Published online: 23 January 2007

(C) Springer Science + Business Media B.V. 2007

\begin{abstract}
The issue of climate change required the development of the Special Report on Emission Scenarios (SRES) by the IPCC. The complexity of the subject and the unique science-policy relation resulted in confusion and discussions appeared in popular media like The Economist. This paper reviews scenario literature and SRES, identifies the most vulnerable elements in the communication of SRES. In the communication of GHG emission scenarios through SRES, the weaknesses that have been identified by the authors of this paper are the normative character of climate change assessment, the plausibility of the scenarios, and the risk of simplification of complex messages. The causes of these communicative issues have been identified as the intrinsic difficulties of interdisciplinary science, the uniqueness of the science-policy relation, and the need for a high degree of transparency. This paper suggests improving future communication of complex messages from scientists to their audience by means of clear reasoning when communicating with non-scientists, explicitly normative emission scenarios, and increased stakeholder participation in scenario development.
\end{abstract}

\section{Introduction}

The future is uncertain and impossible to predict. However, this uncertainty of the future often needs to be assessed in order to understand the size and nature of environmental threats like climatic change.

Assessing the risk of climatic change differs from old school risk analysis because it is characterised by high risk (EEA 2004), but also by high uncertainty (Grübler and

Based on a presentation at the "IIASA-YSSP uncertainty seminars," 22 July 2004, and the discussions thereafter.

N. J. Schenk $(\bowtie) \cdot$ S. M. Lensink

Centre for Energy and Environmental Studies (IVEM), University of Groningen,

Nijenborg 4, Groningen 9747 AG, The Netherlands

e-mail: n.j.schenk@gmail.com 
Nakicenovic 2001). Climate change can have huge impacts on ecosystems, agriculture, fisheries, and extreme weather events, and thus affects the lives of practically all people on planet earth. The uncertainty, on the other hand, is enormous. The uncertainty associated with future greenhouse gas emissions has been assessed in the Special Report on Emission Scenarios (Nakicenovic et al. 2000, hereafter SRES) of the Intergovernmental Panel on Climate Change (IPCC). Scenario analysis of a wide spectrum of alternative futures is the main method used to assess the uncertainty and knowledge gaps associated with future GHG emissions (SRES, p65). Complex scientific messages being among the most difficult ones to deliver, the paper focuses on the communication in the framework of SRES.

Because of the high impact of IPCC publications and because long-term forecasting is a relatively attractive scientific subject, SRES received a lot of attention. A critique on the measurement of economic output in combination with a lack of understanding of the concept of scenario analysis lead to the Babel-like confusion of tongues in the 'Castles and Henderson affair, ${ }^{1}$ which reached the non-scientific public (The Economist 2003b,c) and affected the trust in the findings of the IPCC. The underlying causes of the confusion are twofold.

First, Castles and Henderson appear not to understand the concept of scenario analysis in general and SRES in particular. While statisticians focus on trends, scenario annalists focus on possible trend-breaking. Scenario analysis in SRES is strategic orientation of what may happen, rather than what is statistically likely to happen. Most of the confusion related to the concept of scenario analysis can be reduced to three communicative issues, i.e., normative elements in the scenarios, probability of the scenarios, and simplifications of the scenarios, which is elaborated in Section 3.

Second, SRES authors do not obey the statistical conventions around the use of Purchasing Power Parities (Miketa 2004). ${ }^{2}$ They anticipate that the difference in pricelevels between OECD countries and non-OECD counties will diminish as the income-gap between OECD countries and non-OECD counties closes. This method was not documented in SRES, however, but first published years later (Manne et al. 2005). The confusion related to the use of MER vs. PPP is funded in methodological issues, i.e., interdisciplinary science, the stakeholder-involvement, and the degree of transparency, which is elaborated in Section 4.

This paper aims to contribute to a better communication between scientists and their non-scientific audience. Specifically, the paper reviews scenario literature and SRES in Section 2. Section 3 identifies the most vulnerable elements in the communication of SRES. The latter elements are commented upon in Section 4 to explain them being sources of miscommunication. The concluding remarks should give guidance to reduce the risk of

\footnotetext{
${ }^{1}$ Castles and Henderson put together a critique on SRES. Their main points of criticism were the metric for economic output, Market Exchange Rates (MER) rather than Purchasing Power Parities (PPP), and the plausibility of the scenarios that assume gap-closing between income levels in OECD countries and nonOECD countries. A group of authors connected with SRES responded to the critique, followed by a reply from Castles and Henderson, and again a response from a group of SRES authors (Castles and Henderson 2003a,b; Grübler et al. 2004; Nakicenovic et al. 2003). Castles and Henderson argue that, when PPP is used instead of MER, the base-year levels of developing countries are much higher. Consequently the projections of economic output are also much higher.

2 "Purchasing Power Parities (PPPs) are currency conversion rates that both convert to a common currency and equalise the purchasing power of different currencies. In other words, they eliminate the differences in price levels between countries in the process of conversion." (OECD 2005). PPP is the preferred quantity of economic output among economists (Maddison 2004).
} 
miscommunication and thus offering suggestions to improve future communication of complex messages from scientists to their audience.

\section{Description of IPCC emissions scenarios}

The United Nations Conference on Environment and Development in 1992 in Rio de Janeiro (UNCED 1992) made the curbing of greenhouse gasses (GHG) an important issue on the international political agenda. Most developed countries ${ }^{3}$ committed themselves to do so in the Kyoto protocol (UNFCCC 1997).

SRES was developed because the IPCC needed new scenarios for their Third Assessment Report (TAR). The reasons for new scenarios were both developments that differed from the assumptions within earlier IPCC scenarios, and new insights in scenario analysis (SRES, p66). ${ }^{4}$ The objectives of SRES are threefold (SRES, p64):

- To provide input for evaluating climatic and environmental consequences of alternative future GHG emissions in the absence of specific measures to reduce such emissions or enhance GHG sinks.

- To provide input for assessing mitigation and adaptation possibilities, and their costs, in different regions and economic sectors.

- To provide input to negotiations of possible agreements to reduce GHG emissions.

The first two objectives relate to TAR. The third objective suggests a wide use of the scenarios outside the scientific arena.

A specification of SRES is to "cover a wide spectrum of alternative futures to reflect relevant uncertainties and knowledge gaps" (SRES, p65), and therefore SRES assesses uncertainties associated with climate change issues. SRES is, however, limited to so-called non-intervention scenarios because "SRES scenarios do not include any explicit additional climate policy initiatives in accordance with the Terms of Reference" (SRES, p81). ${ }^{5}$

The method used in SRES is scenario analysis, although elements from other forecasting techniques have also been used. Trend extrapolation ${ }^{6}$ has been used to identify relations between scenario drivers, e.g., the relation between income and energy intensity (SRES, p125). Analogous thinking ${ }^{7}$ is not explicitly used; however, SRES assumes a certain consistency of the development paths of non-OECD countries and OECD countries. ${ }^{8}$ Delphi-like methods ${ }^{9}$ have been used to construct the storylines. Relevance tree analysis ${ }^{10}$

\footnotetext{
${ }^{3}$ The United States are a notable exception.

${ }^{4}$ E.g., legislative changes like the Clean Air Act in the US, and the need for gap-closing scenarios (see Section 3).

${ }^{5}$ Note: the authors of this paper cannot find such a restriction in the 'Terms of Reference' (SRES, p324-325).

${ }^{6}$ Extrapolation of historic trends.

${ }^{7}$ Assuming analogies between future developments of non-OECD (developing) countries and past developments of OECD (developed) countries.

${ }^{8}$ Future rates of change of indicators like 'energy intensity' in non-OECD countries are within the boundaries of historic fast and slow changes in OECD countries.

${ }^{9}$ The 'Delphi method' was developed by the RAND Corporation in the 1950s as a method for gathering information about the future in order to study future non-surface inter-continental warfare in a broad way. It is based on an iterative process of thesis, antithesis, and synthesis, with synthesis becoming the new thesis. The goal is consensus building among experts (Ringland 1998, p19).

${ }^{10}$ Analysis of main drivers of change.
} 
has been used in terms of analysis of key driving forces of GHG emissions. Using the latter methods and techniques, SRES first developed four storylines and next developed scenarios based on the storylines. ${ }^{11}$ Scenarios ${ }^{12}$ that are based on the same storyline ${ }^{13}$ are said to belong to the same scenario family (SRES, pp69-71). Based on the four scenario families, six scenario groups were developed. ${ }^{14}$ There is no traditional trend/Business-as-Usual scenario (Craig et al. 2002; Turkenburg 1993), because the long-term scope of the climate change problem requires strategic orientation on several possible developments. In SRES, there are four so-called scenario families and all scenarios are "equally possible" (SRES, p172). The scenarios "represent pertinent, plausible alternative futures" (SRES, p64).

The scenarios are labeled along two orthogonal axes: (1) Global vs. Regional, and (2) Economic vs. Environmental (SRES, p170; see Fig. 1). Each of the four scenario families is built on a set of (qualitative) assumptions and GDP projections that form a coherent storyline. Some SRES authors state that the socio-economic variables cannot be combined freely ${ }^{15}$ and the SRES authors attempted to combine them based on their interdependency (Grübler and Nakicenovic 2001).

"SRES was designed to provide insights on uncertainty from a range of plausible scenarios" (Grübler et al. 2004). SRES concludes a high uncertainty of future GHG emissions, ranging from low levels (B1, A1T) to very high levels (A2, A1FI) in 2100 (see Fig. 2). It should be noted that higher economic growth does not automatically result in higher GHG emissions, and that within one scenario family very different emission paths are possible (see e.g., different Al scenarios in Fig. 2). Both low and high emission scenarios are treated as "equally possible" in SRES (p172) and "probabilities or likelihoods are not assigned to individual SRES scenarios" (SRES, p315). Section 3.2 elaborates on the plausibility, possibility, and probability of the scenario families.

\section{SRES and communicative issues}

The three main communicative issues, the use of descriptive scenarios, plausibility of the scenarios, and simplification of complex messages, are discussed in separate sections below. It should be noted that there appear to be some inconsistencies in SRES and between SRES and separate publications about SRES by SRES-authors regarding the desirability and probability of the scenarios. Regarding the desirability some individual SRES authors state that SRES describes the B1 world as rather desirable (van Vuuren and de Vries 2001), ${ }^{16}$ while the scenarios are not intended to be desirable (or undesirable) and do not

\footnotetext{
${ }^{11}$ A total of 40 scenarios were developed.

12 "Scenario (generic): A plausible and often simplified description of how the future may develop, based on a coherent and internally consistent set of assumptions about key driving forces (e.g., rate of technology change, prices) and relationships. Scenarios are neither predictions nor forecasts and sometimes may be based on a "narrative storyline." Scenarios may be derived from projections, but are often based on additional information from other sources." (IPCC 2004).

13 "(Scenario) Storyline: A narrative description of a scenario (or family of scenarios) highlighting the main scenario characteristics, relationships between key driving forces, and the dynamics of their evolution." (IPCC 2004).

${ }^{14} \mathrm{~A} 1 \mathrm{~B}, \mathrm{~A} 2, \mathrm{~B} 1, \mathrm{~B} 2, \mathrm{~A} 1 \mathrm{~T}$, and A1FI.

${ }^{15}$ E.g., zero economic growth cannot be combined with rapid technological change and productivity growth (Grübler and Nakicenovic 2001).

16 "A prosperous and fair world (with) a general orientation towards sustainable development."

Springer
} 


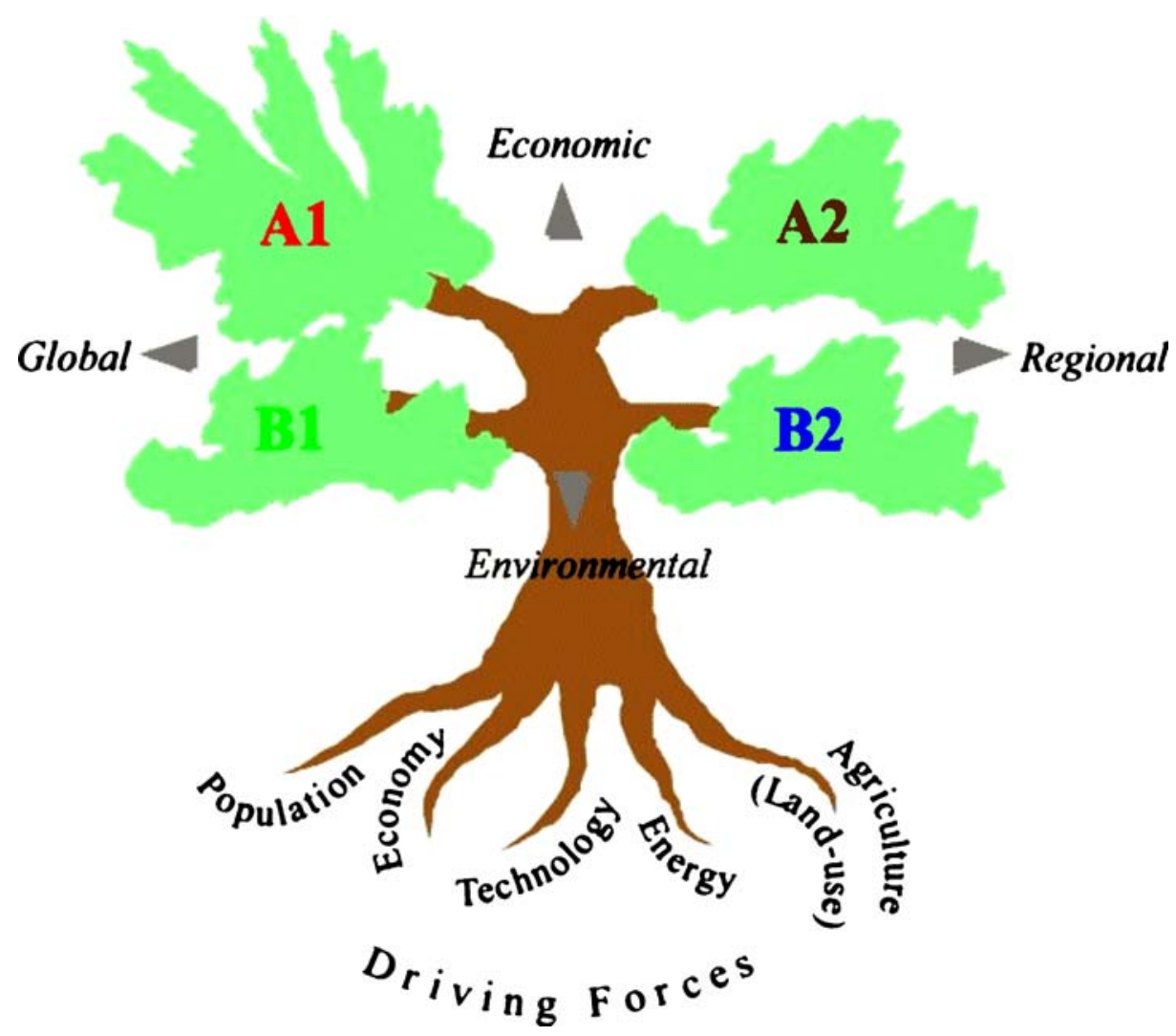

Fig. 1 Relative orientation of the four SRES scenario families

represent preferred developments (SRES, p64). Regarding the probability the scenarios are treated as equally possible (SRES 4.2.1) and thus do not have a Business-as-Usual scenario (SRES, p172), while some individual SRES authors consider the B2 world as Dynamics-asUsual (Kram et al. 2000; Riahi and Roehrl 2000). ${ }^{17}$ The inconsistencies shown by the SRES authors ${ }^{18}$ illustrate the difficulties and pitfalls associated with the SRES message. The question that comes to mind is how policymakers should be able to cope with these issues if even the authors show their struggles to do so.

\subsection{The use of descriptive scenarios to assess a normative problem}

Scenarios cannot be value free (SRES, p64). The SRES scenarios are intended to be descriptive, however, not normative (SRES, p64). The use of descriptive scenarios is indeed the common approach for model-oriented science, but it is also associated with possible pitfalls.

\footnotetext{
${ }^{17}$ While the audience, by lack of guidance, makes its own choices and is allowed to choose even A1FI as 'business-as-usual' (Hillman 2004, p19, p48).

${ }^{18}$ IPCC scientists should clarify their position if there is any chance on confusion (Kaiser 2005).
} 
(a) A1

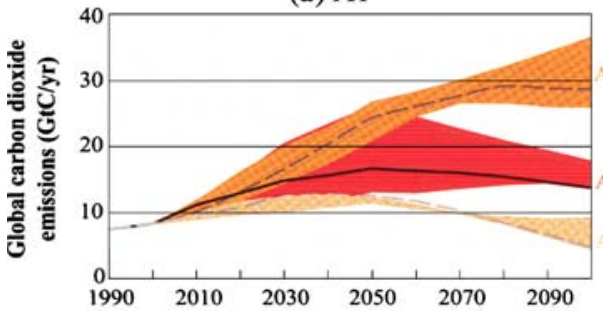

(c) B1

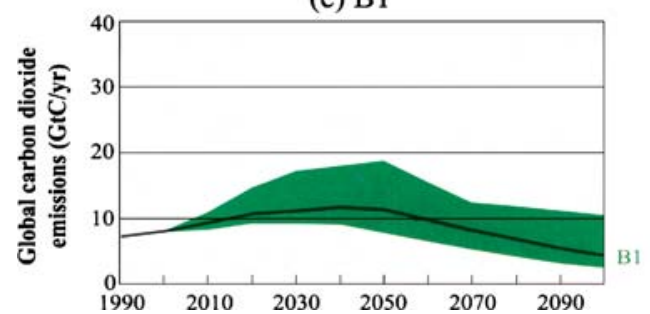

(b) A2

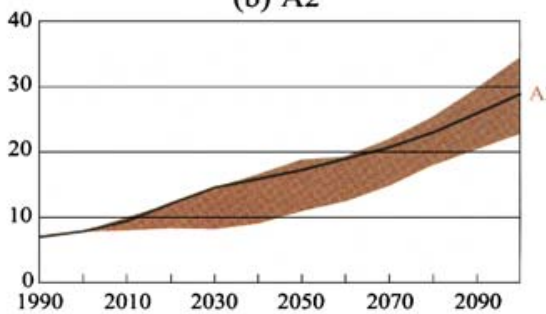

(d) B2

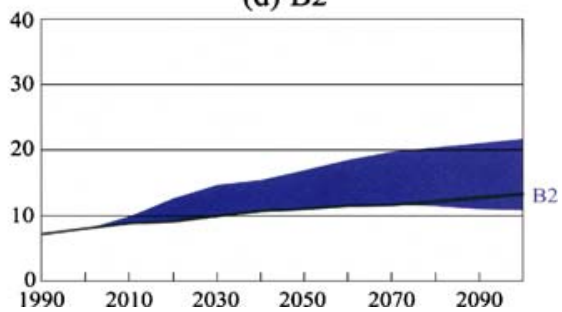

Fig. $2 \mathrm{CO} 2$ emissions of the four SRES scenario families

Although scenarios are meant to be descriptive, some normative elements have entered into the storylines. This is unavoidable. It is also unavoidable that some scenarios are preferred over others by the scenario developers. The B1 scenario is generally seen as positive and A2 as negative (Castles and Henderson 2003a; Kram et al. 2000, as interpreted by Lomborg 2001, p282; Muskulus and Jacob 2005; Smith et al. 2000; Trnka et al. 2004).

In SRES a strong welfare network (SRES, p182) is added unnecessarily ${ }^{19}$ to the aggregation of assumptions that led to the optimistic B1 scenario. By adding this politically-coloured element to the optimistic B1 scenario, SRES seems to take position in the debate around welfare networks. Similarly SRES seems to take position against marketbased solutions by adding this policy instrument to the aggregation of assumptions that led to the materialistic A1 world and opposite to the one leading to the sustainable development oriented B1 world. Therefore SRES is suggestive in representing the worldview of certain parties, and to favour certain parties' solutions for problems. ${ }^{20,21}$ Remarkably market-based solutions are amongst the most effective policy options to address the main environmental problems and to achieve sustainable development (OECD 2001b, Ch 25). However in SRES, market-based solutions are associated with the A1 scenario that is positioned in contrast to sustainable development.

Some SRES authors state that the scenario variables are interdependent (Grübler and Nakicenovic 2001). In SRES socio-economic variables and policies are aggregated according to their assumed interdependency. However, the combinations of socio-economic

\footnotetext{
${ }^{19}$ SRES does not explain why the strong welfare network is added to the B1 scenario, nor does SRES cite literature underpinning the causal relation between strong welfare networks and the sustainable development oriented B1 world.

${ }^{20}$ E.g., the RIVM couples worldviews and political parties to SRES-based scenarios (RIVM 2004, p50-51).

${ }^{21}$ Reviewers of this paper state that we do not understand SRES by saying that SRES is suggestive in representing the worldview of certain parties. Nevertheless we chose to keep our statement as an illustrative example of a possible misinterpretation of SRES.
} 

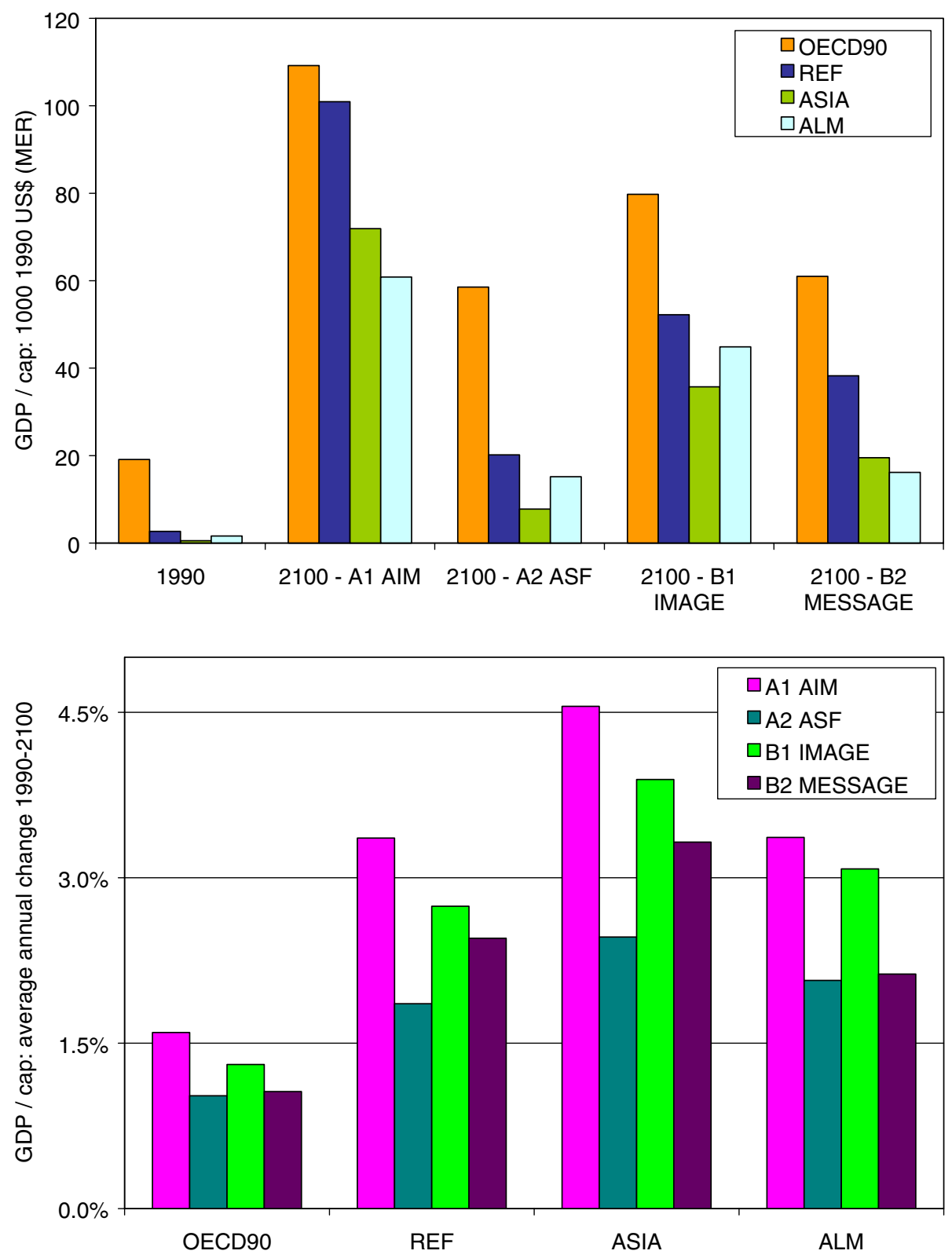

Source: calculated from the IPCC website (http://sres.ciesin.org/final_data.html)

Fig. 3 Income in SRES scenarios

variables and policies are based on opinions. Therefore, value-loaded elements are unnecessarily incorporated in scenarios that are intended to be descriptive. The statement in SRES that the variables are interdependent is therefore also a statement that e.g., marketideology and sustainable development are incompatible. 
In SRES the aggregation of the scenario variables is disputable and the impression is given that the aggregation is based on the worldviews of the scenario developers. Political goals and political means are mixed up in such a way that mainly Western European leftwing parties see their worldviews recognisably represented in the SRES scenarios. As for an example, global sustainability is associated with "improved equity" (SRES, p174), and "a strong welfare net" (SRES, p182). In a paper describing the IMAGE-B2 scenario $^{22}$ some SRES authors associate global sustainability with the market ideology becoming less dominant (de Vries et al. 2000) and SRES associates market-based solutions with the seemingly unsustainable A1 world (SRES, 4.3.1). By incorporating the left-wing dogmas that sustainable development is associated with planned economies (less market ideology) ${ }^{23}$ and levelling of income (improved equity and strong welfare net), SRES can be seen as stoutly offensive against some in other parts of the geographical and political spectrum, like US Republicans. ${ }^{24}$

An obvious normative element in SRES is the income gap closure between OECD countries and non-OECD countries (see Fig. 3). In the evaluation of previous IPCC emission scenarios it was concluded that scenarios with a significant closure of the income gap between OECD and non-OECD countries was needed (SRES, p66, p123) (Alcamo et al. 1995). There was, however, no scientific reasoning in Alcamo et al. to incorporate such a development path in SRES. Apparently the urge to avoid 'Being unfair to the South' (Parikh 1992) was sufficient to include scenarios with implausible high growth rates for developing regions (see Section 3.2). Being fair does not seem to be very compatible with descriptive scenario development, to say the least.

SRES is vulnerable because of its attempt to be descriptive. ${ }^{25}$ The normative elements that entered into SRES made it prone to be misused to justify political opinions, especially because the normative elements in SRES have an air of favouring certain parties and certain parties' solutions for problems. Most problems with normative elements could be avoided by explicitly labelling them as normative. It is less offending for people who do not agree with normative elements, if these elements are presented as normative rather than subjective science. The subject is too normative to be handled with descriptive scenarios (Swart et al. 2004).

\subsection{Plausibility, possibility, probability, and pertinence of the scenarios}

According to SRES, the scenarios "represent pertinent, plausible alternative futures" $\left(\right.$ SRES, p64) ${ }^{26,27}$ which are "treated as equally possible" (SRES, p172), ${ }^{28}$ and "no single scenario was treated as more or less 'probable' than others belonging to the same family" (SRES, p176). ${ }^{29}$

\footnotetext{
22 One of the six marker-scenarios.

${ }^{23}$ Free and fair trade - and thus market ideology becoming more dominant - is a necessity for non-OECD countries to fight poverty (Bhagwati 2004; Hertz 2004).

24 "The American way of life is not up for negotiation." the elder George Bush at the first Earth Summit in Rio de Janeiro in 1992 (The Economist 2003a).

25 "The SRES scenarios are descriptive" (SRES, p64).

${ }^{26}$ Pertinent: "relevant to something" (Oxford Dictionary).

27 Plausible: "seeming to be right or reasonable" (Oxford Dictionary).

${ }^{28}$ Possible: "that can exist or happen, though not certain to" (Oxford Dictionary).

${ }^{29}$ Probable: "likely to happen, exist or be true"(Oxford Dictionary). 
According to SRES the plausibility of the scenarios is based on an extensive review of the emissions scenarios available in the literature, and has been tested by alternative modeling approaches, by peer review, and by the IPCC review and approval process (SRES, p64). Nevertheless the plausibility, possibility, persistency, and/or probability of the scenarios has been the main topic of dispute in the literature (Allen 2003; Grübler and Nakicenovic 2001; Kriegler and Bruckner 2004; Lempert et al. 2004; Lomborg 2001, p280-287; Pittock 2002; Pittock et al. 2001; Reilly et al. 2001; Schneider 2001; Schneider and Mastrandrea 2005; Webster et al. 2003), especially the Castles and Henderson critique (Castles and Henderson 2003a,b; Grübler et al. 2004; Nakicenovic et al. 2003). In this section, the economic development in the A1 AIM marker scenario (see Fig. 3) is used to illustrate communicative issues linked to the concepts of plausibility, possibility, persistency, and probability.

Historical GDP per capita growth has been as high as $8 \%$ for Japan in the period 19501973, but in terms of half a century (half the period SRES considers) annual growth rates have not exceeded 3\% (Maddison 2001, p126). As Fig. 3 shows several SRES scenarios include growth rates of over 3\% for a hundred years period (see also McKibbin et al. 2004a,b). If such scenarios can be considered possible and plausible depends on the context. Unfortunately in SRES context for these high growth scenarios is not sufficiently provided in the sections dealing with economic development (SRES, p92-95, 194-200). In the context of historic developments and scientific knowledge on economic growth, the high growth scenarios are not plausible. Nevertheless scenario developers can alter the context is such a way that high growth scenarios become plausible. High growth scenarios are not impossible, because without restrictions everything is possible. ${ }^{30}$ SRES authors do, however, restrict the reach of 'possible' by stating that: "it is not possible to treat uncertainties of future demographic, economic, and technological developments as independent." (SRES 3.3.3), and "a 'free,' or 'modeler's choice,' numeric combination of scenario indicators is simply not possible." (SRES 4.4.2.1). Therefore SRES authors do base the reach of possible on logic derived from past developments. From this particular interpretation of possible, the high growth scenarios seem impossible. Only clear reasoning can provide the context to consider the high growth as possible and plausible. SRES lacks to provide such a context and without a clear given context readers will create their own context.

The plausibility of so-called non-intervention scenarios (no action taken to curb GHG emissions, hereafter 'baseline scenarios') is awkward anyway because implementing no policy at all is not likely to occur. As for an example, the sustainable development oriented B1 scenario covers policies against e.g., acidification (SRES, p65, specification 7) and at the same time implements no GHG policies at all. It is rather unlikely, and not plausible, that action is taken against all environmental treats except for climatic change. Including such policies affect the baseline character of the scenarios. ${ }^{31}$

The SRES scenario families are not equally plausible. Scenarios that explore the upper or lower boundaries of salient scenario driving forces (Nakicenovic et al. 2003) are differently (not less!) plausible than 'dynamics-as-usual' scenarios. In analogy the plausibility of 'optimistic' or 'pessimistic' scenarios are differently plausible than neutral scenarios. Moreover, as mentioned in footnote 25, free and fair trade - and thus market

\footnotetext{
30 "Nothing is impossible, just improbable." (Douglas Adams' Hitchhikers guide to the galaxy).

${ }^{31}$ It could be argued that this is a false ceteris paribus condition because stringent environmental policies in the absence of GHG policies are not plausible. For a line of reasoning that the "no-control" assumption can be consistent with a global focus to sustainable development see: (de Vries et al. 2000).
} 
ideology becoming more dominant - is a necessity for non-OECD countries to develop and overcome poverty according to mainstream economic thought (Bhagwati 2004; Hertz 2004). Therefore, associating high economic growth in non-OECD counties with market ideology becoming less dominant is implausible.

Treating the scenarios as "equally possible" confuses the communication because they are obviously not. Without likelihood assessment scenario analysis looses a lot of weight (Schneider 2001) and, in our opinion, becomes a toothless tiger. Therefore the plausibility needs to be assessed. The assessment however, does not necessarily need to be as quantitative as suggested (Schneider 2001). Quantitative assessment with probability distribution functions, as performed by Mastrandrea and Schneider (2004), tends to pull the focus of the audience towards dynamics-as-usual scenarios. Assessment of plausibility can alternatively be performed qualitatively by labeling the scenarios explicitly. Experiences from the Shell scenario group tell that likelihood assessment, although mostly qualitative, is a key factor in the communication process (Schwartz 1998). The communication of the scenarios can be improved by naming the scenarios in such a way that the names appeal to the intuition of the audience. Qualitative assessment by explicitly labelling the scenarios according to their plausibility can overcome the plausibility dilemma without incorporating the disadvantages of probability distributions.

Castles and Henderson would probably not have been targeting the plausibility of the SRES scenarios when B1 would have been labelled as 'extremely optimistic' regarding the economic development of non-OECD countries. SRES would not have been such an easy target when normative elements would have been labelled explicitly as normative (see e.g., Schneider and Mastrandrea 2005).

\subsection{The risk of simplification}

The message of SRES is a complex one with counter-intuitive elements. In a nutshell, SRES concludes that scenarios with different socio-economic drivers can lead to similar cumulative emissions, while similar driving forces can branch out into different categories of cumulative emissions (SRES, p315). According to some authors, SRES contains the message that lower GDP does not automatically leads to lower emissions and that high GDP does not automatically lead to higher emissions (Grübler et al. 2004). The concept of sustainable development is an integrated part of SRES. The concept of sustainable development does not oppose economic development to the environment.

In the storylines and the $2 \times 2$ matrix, economic orientation and environmental orientation are presented as opposites (see Fig. 1). ${ }^{32}$ The presentation of the economy and the environment as opposites has potentially a very high impact on the communication of SRES, because it polarises the discussion to pre-sustainable development logic, where economic development and the environment are seen as opposites (Schwartz 1998). Quite the opposite of the message SRES intended to bring. Moreover putting Economy and Environment as opposites on one axis (SRES, p170) implies a choice between economy and environment. It therefore makes the SRES prone to be used to justify political choices without SRES providing any solid justification for those choices. It is considered one of the

\footnotetext{
32 There is no strong scientific support for both environmental degradation as a consequence of economic growth, and, more important for the concept of sustainable development, reduced economic growth as a consequence of tighter environmental policy (Chua 1999). Moreover, there is no a priori reason for economic activity to harm the environment, use energy, or emit GHGs (Chua 1999; Craig et al. 2002; Schipper et al. 2001; Smil 2000).
} 
potential vulnerabilities of scenarios (Keepin and Wynne 1984), especially because opposing 'Economy' to 'Environment' seems to support the worldview of only a single part of the political spectrum. Alternative ideologies, like the one supported by the current Dutch minister of economic affairs, consider economic growth as a necessary, although not sufficient, condition to implement environmental policies (Brinkhorst 2004). Those politicians see their worldview neglected by the IPCC in the $2 \times 2$ matrix, in Fig. 1 .

\section{Discussion and conclusions}

The issues mentioned in the previous Section 3 arise from the interdisciplinary character of SRES, the extraordinary relation between science and policy, and lack of transparency of the report. These issues are discussed below.

\subsection{Interdisciplinary science}

Performing interdisciplinary science requires scientists from all disciplines that are directly related to the subject. Watson states that the TAR, and thus SRES, is characterized by insufficient involvement of leading macro-economists (Watson 2002). The dispute with Castles and Henderson can be seen as an exponent of this insufficient involvement of leading macro-economists.

The absence of scientists from relevant disciplines is reflected in the choice of the key driving forces identified in SRES. There is a strong emphasis on easily quantifiable drivers like GDP, population, and technology, but other drivers like institutional frameworks, are only vaguely discussed in the storylines. See for comparison the more comprehensive assessment of driving forces in the OECD Environmental Outlook (OECD 2001b) and Global Environment Outlook 3 scenarios (Bakkes et al. 2004).

The insufficient involvement of leading macro-economists (Watson 2002) ended in nonspecialist scientists to perform advanced economic tasks, thus ignoring the importance of economics regarding long-term energy scenarios. This apparent attitude disturbs the communication with the economic community, and with one of the stakeholders in the sustainability debate. ${ }^{33}$ When performing multidisciplinary science, the mono-disciplinary sciences should not be ignored. As for a comparison, in the OECD Environmental Outlook (OECD 2001b) the economic part of the research was conducted by OECD, ${ }^{34}$ while the environmental pressures were handled by the Stockholm Environment Institute - Boston ${ }^{35}$ (Kemp-Benedict and Raskin 2001; Schenk 2000). Approval of leading macro-economists is needed to build trust in the economic projections.

\subsection{Science-policy relation}

Because of the high stakes and high uncertainties, the science-policy interface of climatic change is the domain of so-called post-normal science (Funtowicz and Ravetz 1993). Moreover, climatic change issues deal with e.g., inter-generational justice, long-term

\footnotetext{
${ }^{33}$ E.g., the choice of the SRES authors to disregard the statistical conventions has confused the discussion regarding the use of PPP and MER to a great extent (Miketa 2004).

${ }^{34}$ http://www.oecd.org/

35 http://www.seib.org/
} 
effects, and huge time-lags between cause and effect. Justice is normative, and therefore climate change issues are normative (Schneider and Mastrandrea 2005). The use of descriptive scenarios for a normative problem leads to the conflicts described in Section 3.1. The communication can be improved by the development of normative but consistent scenarios, preferably developed in co-operation with relevant stakeholders.

The post-normal science-policy relation requires extension of the peer communities (Funtowicz and Ravetz 1993). Therefore, policy makers should be involved in an early stage of the scientific process. The policy makers should be involved in the model development, similar to the UN ECE acid rain negotiations (Tuinstra et al. 1999). Similarly in the OECD Environmental Outlook and Strategy program (OECD 2001a,b) a steering committee (with policy makers) was involved in order to make sure the scientists answered the questions the policymakers wanted. The steering committee also helped to avoid issues that were too politically sensitive and could potentially block the acceptance of the reports. Additionally a draft of the report received comments during a High Level Segment meeting of the OECD Environmental Policy Committee (EPOC). In the process of the next OECD Environmental Outlook the policy makers from all OECD countries, except The Netherlands, demanded for a single reference scenario instead of several scenarios analogous to SRES (Visser, 2004, personal communication).

The unique science-policy relation urges to go beyond the traditional science-policy relation (Funtowicz and Ravetz 1993). Stakeholder analysis (know who the stakeholders are and what they want) and stakeholder-involved scenario development has a huge potential in climate change issues (van Grinsven, 2004, personal communication). Stakeholder involvement requires, however, a different approach towards scenario development, like stakeholder-involved scenario development. The role of the scientists would be to provide guidance to the stakeholders.

\subsection{Transparency}

Being transparent is one of SRES' own specifications (SRES, p65, specification 8). One can argue that SRES itself is insufficiently transparent. While much information could have been presented in a more concise manner, information about the key socio-economic driving forces (population and GDP) is presented only in tables or unclear graphs. Historic developments as well as projections, presented with both absolute levels and average annual changes of key drivers, would allow readers to compare consequences of the different scenarios at a glance.

It is unclear whether the four SRES scenarios sufficiently cover a wide spectrum of alternative futures (SRES, p65, specification $3 \& 8$ ) with the division in global vs. regional and economic vs. environmental. SRES does not elaborate on the sufficiency of the scenarios to meet the objective of covering the uncertainties.

SRES aims to assess the uncertainty in driving forces by means of the IPAT identity ${ }^{36}$ to organise the discussion on GHG emission driving forces (SRES, p105). However, by doing so SRES unwillingly understates the relative importance of key driving forces like institutional frameworks (OECD, 2001b).

${ }^{36} I=\mathrm{P}^{*} \mathrm{~A} * \mathrm{~T}$, with $\mathrm{I}$ : environmental impact; P: population; A: affluence (GDP/P); T: technology (I/GDP), (Ehrlich and Holdren 1971; Kaya 1990). 
The use of six models does not improve transparency. The main document should also explain why specifically the used models (not more, less or other) cover the uncertainty due to models structure. Despite the many pages, the conceptual differences between the models are not transparently described and discussed in the report. The communication and reliability would increase with the use of one official model and several supportive models, analogous to the modeling framework of the UN ECE acid rain negotiations (Tuinstra et al. 1999).

There is much information on general background information, but how exactly storylines were quantified into model input parameters is not transparently presented. Transparent information about the assumptions and the relative importance of the assumptions is needed. Eye-balling the shapes of the carbon dioxide emissions scenarios suggest that fossil resource availability plays a dominant role in the differences between the scenarios. Although uncertainty analysis has been performed (e.g., in van der Sluijs et al. 2001), the transparency could improve by presenting a simplified but representative sensitivity analysis in a transparent way in the main document.

Transparency about normative elements potentially increases the communication. Stakeholder-involved scenario development makes it easier for the scientists to identify normative elements and label them explicitly.

\section{Concluding remarks}

In the communication of GHG emission scenarios through SRES, the weaknesses that have been identified by the authors of this paper are the normative character of climate change assessment (Section 3.1), the plausibility of the scenarios (Section 3.2), and the risk of simplification of complex messages (Section 3.3). The causes of these communicative issues have been identified as the intrinsic difficulties of interdisciplinary science (Section 4.1), the uniqueness of the science-policy relation (Section 4.2), and the need for a high degree of transparency (Section 4.3).

Our main message to scenario developers is therefore: 'Keep It Simple, Scientists' (KISS). Above all the reader needs clear reasoning. Scientific conclusions are to be discussed in scientific journals and the switching to a different modus is required whenever writing reports like SRES. The summaries in SRES are too vague. It matters what the stakeholders need to know, rather than what the scientists think the stakeholder needs to know.

The extraordinary science-policy relation (Section 4.2) means extreme caution and changes the way of conducting science (Funtowicz and Ravetz 1993). The use of cultural perspectives is common in environmental sciences (de Vries 2001; Moll 1993; Noorman 1995) but should not be used in post-normal science because one risks the perception of the moral superiority ${ }^{37}$ of one worldview over the other. In SRES the apparent moral superiority of the B1 scenario over the others disturbs the dialogue with important stakeholders.

The normative character of climate change scenarios (Section 3.1) requires explicitly normative emission scenarios. Stakeholder participation in scenario development enables stakeholder groups to obtain sets of scenarios suitable for their specific situation. Experiences with stakeholder participation in scenario development shows the relevance

${ }^{37}$ During the Athenian democracy in ancient times, many well-known politicians were ostracised because the citizens could not bear their moral superiority (Greene 1998, Ch. 42). 
of such an approach (Carlsson-Kanyama et al. 2003). On the other hand, scientists should confront stakeholders with limitations obtained from scientific knowledge. In order not to loose their reliability and credibility, scientists should not give into ridiculous demands from stakeholders, like the non-intervention restriction (SRES, p81).

Acknowledgments A significant share of the realisation of this paper was done during the IIASA Young Scientist Summer Program (YSSP) 2004. Several people contributed to this paper by means of discussions on this subject and by reviewing this paper. We would like to thank them all: Asami Miketa, Keywan Riahi, Leo Schrattenholzer, and Hal Turton all from the International Institute for Applied Systems Analysis (IIASA) Environmentally Compatible Energy Strategies (ECS) Program. Peter van Grinsven from the IIASA Processes of International Negotiation (PIN) project and Clingendael Institute. Bert de Vries from the Dutch National Institute for Public Health and the Environment (RIVM). Jan Bakkes and Rob Visser of the Organisation for Economic Co-operation and Development (OECD). Winnie Gerbens, Michiel Hekkenberg, Annemarie Kerkhof, Henk Moll, Ton Schoot Uiterkamp from the Center for Energy and Environmental Studies (IVEM) at the University of Groningen. We thank the anonymous reviewers of this journal for valuable remarks and suggestions.

\section{References}

Alcamo J, Bouwman A, Edmonds J, Grübler A, Morita T, Sugandhy A (1995) An evaluation of the IPCC IS92 emission scenarios. In: Houghton JT, Meira Filho LG, Bruce J, Lee H, Callander BA, Haites E, Harris N, Maskell K (eds) Radiative forcing of climate change and an evaluation of the IPCC IS92 emission scenarios. Cambridge University Press, Cambridge, UK, pp 233-304

Allen M (2003) Possible or probable?. Nature 425:242 (18 SEPTEMBER)

Bakkes J, Henrichs T, Kemp-Benedict E, Masui T, Nellemann C, Potting JMB, Rana A, Raskin P, and Rothman DS (2004) The GEO-3 scenarios 2002-2032: quantification and analysis of environmental impacts'. No. UNEP/DEWA/RS.03-4 and RIVM 402001022, United Nations Environment Programme (UNEP)/National Institute for Public Health and the Environment (RIVM)

Bhagwati J (2004) In defense of globalization. Oxford University Press, New York

Brinkhorst LJ (2004) Hoe meer groei, hoe beter voor het milieu (the more growth, the better for the environment). De Volkskrant (6 September)

Carlsson-Kanyama A, Dreborg KH, Eenkorn BR, Engström R, Falkena HJ, Gatersleben B, Hendriksson G, Kok R, Moll HC, Padovan D, Rigoni F, Stø E, Throne-Holst H, Tite L, and Vittersø G (2003) Images of everyday life in the future sustainable city: experiences of back-casting with stakeholders in five European cities. No. 19, Forskningsgruppen för Miljöstrategiska Studier (FMS), Stockholm, Sweden

Castles I, Henderson D (2003a) Economics, emissions scenarios and the work of the IPCC. Energy Environ 14(4):415-435

Castles I, Henderson D (2003b) The IPCC emission scenarios: an economic-statistical critique. Energy Environ 14(2\&3):159-185

Chua S (1999) Economic growth, liberalization, and the environment: a review of the economic evidence. Annu Rev Energy Environ 24:391-430

Craig PP, Gadgil A, Koomey JG (2002) What can history teach us? a retrospective examination of long-term energy forecasts for the United States. Annu Rev Energy Environ 27:83-118

de Vries HJM (2001) Objective science? The case of climate change models. In: Goujon P, Heriard Dubreuil B (eds) Technology and ethics, a European quest for responsible engineering. Peeters, Leuven, Belgium, pp $485-510$

de Vries B, Bollen J, Bouwman L, den Elzen M, Janssen M, Kreileman E (2000) Greenhouse gas emissions in an equity-, environment- and service-oriented world: an IMAGE-based scenario for the 21st century. Technol Forecast Soc Change 63(2-3):137-174

EEA (2004) Impacts of Europe's changing climate - an indicator-based assessment. EEA Report, No. 2/ 2004, European Environmental Agency, Copenhagen, Denmark

Ehrlich PR, Holdren JP (1971) Impact of population growth. Science 171:1212-1217

Funtowicz SO, Ravetz JR (1993) Science for the post-normal age. Futures 25(7):739-755

Greene R (1998) The 48 laws of power. Viking, New York 
Grübler A, Nakicenovic N (2001) Identifying dangers in an uncertain climate. Nature 412(6842):15

Grübler A, Nakicenovic N, Alcamo J, Davis G, Fenhann J, Hare M, Mori S, Pepper B, Pitcher H, Riahi K, Rogner HH, La Rovere EL, Sankovski A, Schlesinger ME, Shukla P, Swart R, Victor DG, Jung TY (2004) Emission scenarios: a final response. Energy Environ 15(1):11-24

Hertz N (2004) I.O.U. : the debt threat and why we must defuse it. Harper Perennial, London, UK

Hillman M (2004) How we can save the planet. Penguin, London, UK

IPCC (2004) Climate Change 2001: Synthesis Report, Annex B. Glossary of Terms. Cambridge University Press, Cambridge, UK, pp365-388 On-line available: http://www.ipcc.ch/pub/syrgloss.pdf

Kaiser J (2005) Climate change: scientist quits IPCC panel over comments. Science 307(5709):501b

Kaya Y (1990) Impact of carbon dioxide emission control on GNP growth: interpretation of proposed scenarios. Paper presented to the IPCC Energy and Industry Subgroup, Response Strategies Working Group, Paris, France

Keepin B, Wynne B (1984) Technical analysis of IIASA energy scenarios. Nature 312:691-695

Kemp-Benedict E, Raskin P (2001) Global environmental scenarios: technical notes on use of PoleStar for the OECD Environmental Outlook (Background document for the OECD Environmental Outlook For Modelling and Assessments), Organisation for Economic Co-operation and Development, Paris, France

Kram T, Morita T, Riahi K, Roehrl RA, Van Rooijen S, Sankovski A, de Vries B (2000) Global and regional greenhouse gas emissions scenarios. Technol Forecast Soc Change 63(2-3):335-371

Kriegler E, Bruckner T (2004) Sensitivity analysis of emissions corridors for the 21 st century. Clim Change 66(3):345-387

Lempert R, Nakicenovic N, Sarewitz D, Schlesinger ME (2004) Characterizing climate-change uncertainties for decision-makers: an editorial essay. Clim Change 65:1-9

Lomborg B (2001) The sceptical environmentalist - measuring the real state of the world. Cambridge University Press, Cambridge, UK

Maddison A (2001) The world economy: a millennial perspective. Organisation for Economic Co-operation and Development, Paris, France

Maddison A, 2004. The PPPrice is right. Economist 372(8383):14

Manne A, Richels R, Edmonds J (2005) Market exchange rates or purchasing power parity: does the choice make a difference to the climate debate? Clim Change 71(1-2):1-8

Mastrandrea MD, Schneider SH (2004) Probabilistic integrated assessment of dangerous climate change. Science 304(5670):571-575

McKibbin WJ, Pearce D, Stegman A (2004a) Can the IPCC SRES be improved? Energy Environ 15(3):351362

McKibbin WJ, Pearce D, Stegman A (2004b) Long run projections for climate change scenarios. Brookings Discussion Papers in International Economics, No. 160, The Brookings Institution, Washington (DC). On-line available: http://www.brookings.edu/views/papers/20040415_bdpie160.htm

Miketa A (2004) The use of purchasing power parities in long-term economic growth scenarios, presentation at IIASA. International Institute for Applied System Analysis (IIASA), Laxenburg, Austria

Moll HC (1993) Energy counts and materials matter in models for sustainable development. Ph.D. Thesis: Center for Energy and Environmental Studies (IVEM), University of Groningen, The Netherlands

Muskulus M, Jacob D (2005) Tracking cyclones in regional model data: the future of Mediterranean storms. Advances in Geosciences 2:13-19

Nakicenovic N, Alcamo J, Davis G, de Vries HJM, Fenhann J, Gaffin S, Gregory K, Grübler A, Jung TY, Kram T, La Rovere EL, Michaelis L, Mori S, Morita T, Pepper W, Pitcher H, Price L, Riahi K, Roehrl A, Rogner HH, Sankovski A, Schlesinger ME, Shukla P, Smith S, Swart R, van Rooijen S, Victor N, Dadi Z (2000) Special report on emissions scenarios, international panel on climate change. Cambridge University Press, Cambridge, UK

Nakicenovic N, Grübler A, Gaffin S, Jung TT, Kram T, Morita T, Pitcher H, Riahi K, Schlesinger ME, Shuka PR, van Vuuren DP, Davis G, Michaelis L, Swart R, Victor N (2003) The IPCC emission scenarios: a response. Energy Environ 14(2\&3):187-214

Noorman KJ (1995) Exploring futures from an energy perspective - a Natural Capital Accounting model study into the long-term economic development potential of The Netherlands. Ph.D. Thesis: Center for Energy and Environmental Studies (IVEM), University of Groningen, The Netherlands

OECD (2001a) Environmental Strategy for the First Decade of the 21st Century. Organisation for Economic Co-operation and Development, Paris, France

OECD (2001b) OECD environmental outlook. Organisation for Economic Co-operation and Development, Paris, France

OECD (2005) Purchasing Power Parities (PPP), About, Statistics Directorate. Organisation for Economic Co-operation and Development: http://www.oecd.org/about/0,2337,en_2649_34357_1_1_1_1_1,00.html accessed on 11 October 2005

Parikh JK (1992) IPCC strategies unfair to the south. Nature 360:507-508 
Pittock AB (2002) What we know and don't know about climate change: reflections on the IPCC TAR. Clim Change 53:393-411

Pittock AB, Jones RN, Mitchell CD (2001) Probabilities will help us plan for climate change. Nature 413 (6853):249

Reilly J, Stone PH, Forest CE, Webster MD, Jacoby HD, Prinn RG (2001) Climate change: uncertainty and climate change assessments. Science 293(5529):430a-4433

Riahi K, Roehrl RA (2000) Greenhouse gas emissions in a dynamics-as-usual scenario of economic and energy development. Technol Forecast Soc Change 63(2-3):175-205

Ringland G (1998) Scenario planning. Wiley, Chicester, England

RIVM (2004) Kwaliteit en toekomst: verkenning van duurzaamheid (Quality and future: sustainability outlook). Rijksinstituut voor Volksgezondheid en Milieu (RIVM), Bilthoven. On-line available: http:// www.rivm.nl/bibliotheek/rapporten/duve04001.html

Schenk NJ (2000) Modelling in the EOS Project, presentation for the Advisory Panel of the OECD Environmental Outlook and Strategy (EOS) Project. Organisation for Economic Co-operation and Development (OECD), Paris, France

Schipper L, Unander F, Murtishaw S, Ting M (2001) Indicators of energy use and carbon emissions: explaining the energy economy link. Annu Rev Energy Environ 26:49-81

Schneider SH (2001) What is 'dangerous' climate change? Nature 411(6833):17-19

Schneider SH, Mastrandrea MD (2005). Probabilistic assessment of "dangerous" climate change and emissions pathways. Proc Natl Acad Sci USA 102(2):15728-15735

Schwartz P (1998) The art of the long view-planning for the future in an uncertain world. Wiley, West Sussex, England

Smil V (2000) Energy in the twentieth century: resources, conversions, costs, uses, and consequences. Annu Rev Energy Environ 25:21-51

Smith SJ, Wigley TML, Edmonds J (2000) Climate: a new route toward limiting climate change? Science 290(5494):1109-1110

Swart RJ, Raskin P, Robinson J (2004) The problem of the future: sustainability science and scenario analysis. Glob Environ Change Part A 14(2):137-146

The Economist (2003a) A greener Bush. Economist 366(8311):12-13

The Economist (2003b) Hot potato - the International Panel on Climate Change had better check its calculations. Economist 366(8311):72

The Economist (2003c) Hot potato revisited. Economist 369(8349):76

Trnka M, Dubrovský M, Semerádová D, Zcaronalud Z (2004) Projections of uncertainties in climate change scenarios into expected winter wheat yields. Theor Appl Climatol 77(3-4):229-249

Tuinstra W, Hordijk L, Amann M (1999) Using computer models in international negotiations - the case of acidification in Europe. Environment 41(9):33-42

Turkenburg WC (1993) Forecasting, toegepast op onze energievoorziening (Forecasting, applied to our energy supply). In: Ruiter Wd (ed), Dictaat energie en milieu (Syllabus energy and the environment). University of Utrecht, Utrecht, The Netherlands

UNCED (1992) The Earth summit. United Nations Conference on Environment and Development, New York

UNFCCC (1997) Kyoto protocol to the United Nations Framework Convention on Climate Change, United Nations Framework Convention on Climate Change. United Nations, New York

van der Sluijs JP, Potting JMB, Risbey J, van Vuuren DP, de Vries HJM, Beusen A, Heuberger P, Quintana SC, Funtowicz S, Kloprogge P, Nuijten D, Petersen A, Ravetz J (2001) Uncertainty assessment of the IMAGE/TIMER B1 CO2 emissions scenario, using the NUSAP method'. No. 410200 104, Dutch National Research Program on Climate Change

van Vuuren DP, de Vries HJM (2001) Mitigation scenarios in a world oriented at sustainable development: the role of technology, efficiency and timing. Climate Policy 1(2):189-210

Watson RT (2002) The future of the intergovernmental panel on climate change. Climate Policy 2(4):269-271

Webster MD, Forest CE, Reilly J, Babiker MH, Kicklighter D, Mayer M, Prinn RG, Sarofim M, Sokolov A, Stone PH, Wang C (2003) Uncertainty analysis of climate change and policy response. Clim Change 61:295-320 